\title{
ANALISIS PADA PEMODELAN KEDATANGAN DAN KEBERANGKATAN PENUMPANG BUS RAPID TRANSIT DI KOTA SEMARANG
}

\author{
Berlito Adi Winandanto*, Alfa Narendra \\ Fakultas Teknik, Universitas Negeri Semarang, Jalan Sekaran, Kel. Sekaran, Kec. Gunungpati, Kota Semarang, \\ Jawa Tengah, Indonesia 50229 \\ *berlitoadiw@students.unnes.ac.id
}

\begin{abstract}
ABSTRAK
Kota Semarang merupakan salah satu kota besar yang ada di Indonesia dengan perkembangan perekonomian yang tinggi menjadikan tingginya mobilitas yang terjadi di Kota Semarang. Adanya mobilitas penduduk yang tinggi mengakibatkan kebutuhan akan sarana transportasi darat semakin tinggi. Terutama moda transportasi yang ada di dalam kota dengan aman, cepat, dan murah. Bus Rapid Transit merupakan salah satu moda transportasi darat yang aman, cepat, murah dan nyaman. Oleh sebab itu tingkat pelayanan adalah faktor yang penting untuk diperhatikan. Terdapat banyak halte Bus Rapid Transit yang ada di Kota Semarang. Studi ini menganalisis pola kedatangan penumpang di Halte Simpang Lima dan Halte Kampung Pelangi Kota Semarang. Tujuan dari studi ini adalah untuk menganalisis pola kedatangan penumpang di Halte Simpang Lima dan Halte Kampung Pelangi guna mengoptimalkan tingkat pelayanan. Pengumpulan data dilakukan menggunakan metode survei secara langsung di Halte Simpang Lima dan Halte Kampung Pelangi dengan menghitung penumpang yang datang memasuki dan keluar halte selama 5 jam pada jam puncak selama 3 hari. Dari analisis tersebut kemudian didapat pola kedatangan penumpang Bus Bus Rapid Transit di Halte Simpang Lima Kota Semarang dan Halte Kampung Pelangi selama 5 jam dalam waktu 3 hari dengan pola kedatangan yang beragam terjadi peningkatan penumpang pada hari libur. Hasil yang didapatkan dalam studi ini berguna untuk mengoptimalkan pelayanan.
\end{abstract}

Kata kunci:BRT; halte simpang lima; halte kampung pelangi; pola kedatangan

\section{ANALYSIS ON ARRIVAL MODELING AND PASSENGER DEPARTURES BUS RAPID TRANSIT IN THE CITY OF SEMARANG}

\begin{abstract}
The city of Semarang is one of the major cities in Indonesia with high economic development that makes high mobility that occurs in the city of Semarang. The high population mobility has resulted in the need for land transportation facilities to be higher. Especially the modes of transportation in the city safely, quickly, and cheaply. Bus Rapid Transit is one of the modes of land transportation that is safe, fast, cheap and comfortable. Therefore the level of service is an important factor to consider. There are a lot of Bus Rapid Transit bus stop in Semarang. This study analyzes the arrival patterns of passengers at Simpang Lima bus stop and Kampung Pelangi bus stop in Semarang City. The purpose of this study is to analyze the arrival patterns of passengers at Simpang Lima bus stop and Kampung Pelangi bus stop to optimize service levels. Data collection was carried out using the direct survey method at Simpang Lima bus stop and Kampung Pelangi bus stop by counting passengers who entered and exiting the bus stop for 5 hours at peak hours for 3 days. From this analysis, it was found that the arrival pattern of Bus Rapid Transit bus passengers at Simpang Lima bus stop and Kampung Pelangi bus stop in Semarang city for hours in 3 days with various arrivals patterns increased the number of passengers on holidays. The results obtained in this study are useful for optimizing service.
\end{abstract}

Keywords: BRT; kampung pelangi bus stop; patterns of arrival; simpang lima bus stop

\section{PENDAHULUAN}

Seiring dengan perkembangan kebutuhan yang terjadi di Kota Semarang, mengakibatkan semakin tingginya mobilitas yang terjadi di Kota Semarang, perkembangan ini dapat terjadi karena kota Semarang merupakan ibu kota Provinsi Jawa Tengah. Hal ini membuat Kota Semarang menjadi salah satu kota besar yang ada di Indonesia dengan perkembangan 
perekonomian yang tinggi. Dengan perkembangan perekonomian yang tinggi ini kebutuhan akan transportasi baik berupa darat, udara, atau laut menjadi tinggi. Adanya mobilitas penduduk yang tinggi mengakibatkan kebutuhan akan sarana transportasi terutama transportasi darat semakin tinggi. Terutama moda transportasi yang ada di dalam kota dengan aman, cepat, dan murah. Terdapat berbagai macam moda transportasi darat yang ada di Kota Semarang diantaranya adalah mobil, sepeda motor, taksi, bus, kereta, dll. BRT merupakan salah satu moda transportasi darat yang aman, murah dan nyaman. Moda transportasi BRT ini juga sangat cepat jika ingin menjangkau ke daerah-daerah dalam kota yang ingin dituju. Terdapat banyak sekali halte BRT yang ada di Kota Semarang, diantaranya adalah halte Simpang Lima dan halte Kampung pelangi.

Salah satu penyebab kemacetan didaerah perkotaan adalah meningkatnya kecenderungan para pemakai jasa transportasi untuk menggunakan kendaraan pribadi dibandingkan dengan kendaraan umum yang mengakibatkan semakin padatnya arus lalu lintas. Oleh sebab itu sangat penting adanya fasilitas transportasi umum yang menunjang agar penduduk beralih dari kendaraan pribadi menjadi kendaraan umum yang memadai untuk menampung orang yang menggunakan transportasi umum. Menurunnya peranan angkutan umum juga disebabkan oleh rendahnya tingkat pelayanan angkutan umum itu sendiri. Pada dasarnya, tingkat pelayanan yang rendah itu menyangkut sarana dan prasarana yang kurang memadai, waktu tempuh yang cukup lama, jumlah penumpang yang melebihi kapasitas angkut, tingkat kenyamanan yang rendah, sistem jaringan yang kurang memadai, serta aksesibilitas yang sulit untuk beberapa daerah tertentu. Adapun titik-titik kemacetan sering terjadi di jalan. Oleh karena itu untuk menciptakan transportasi yang lebih baik, efisien dan efektif sebaiknya masyarakat lebih diarahkan untuk menggunkan transportasi umum. Hal ini untuk mengurangi permasalaha-permasalahan kemacetan yang terjadi diruas-ruas jalan. Selain menyebabkan berkurangnya waktu perjalanan dan kemacetan juga dapat mengurangi polusi udara.

Upaya untuk mengatasi hal tersebut Kota Semarang telah melakukan pengambangan Bus Rapid Transit (BRT) guna memperbaiki layanan angkutan perkotan yang ada saat ini. Bus Rapid Transit (BRT) adalah sebuah system bus yang cepat, nyaman, aman dan tepat waktu dari segi insfrastruktur, kendaraan dan jadwal. Operasional Bus Rapid Transit (BRT) Semarang menggandeng pihak swasta untuk mengelolanya. Model antrian adalah model antrian dengan pola kedatangan berdistribusi umum (General), pola pelayanan berdistribusi umum (General), dengan jumlah fasilitas pelayanan sebanyak banyaknya. Disiplin antrian yang digunakan adalah umum yaitu FCFS (First Come First Service), kapasitas maksimum yang diperbolehkan dalam sistem adalah tak hingga, dan memiliki sumber pemanggilan tak hingga (Gross dan Harris, 1998).

Pola kedatangan bisa teratur bisa juga acak (random). Kedatangan yang teratur biasanya sudah ditentukan waktunya, misalnya setiap 30 detik, contohnya kedatangan busway sesuai frekuensi yang sudah ditetapkan. Sedangkan pola kedatangan yang sifatnya acak (random) banyak kita jumpai misalnya kedatangan penumpang busway. Pola kedatangan yang sifatnya acak dapat digambarkan dengan distribusi statistik (Sitohang, 2006). Pola kedatangan adalah pola pembentukan antrian akibat kedatangan customer dalam selang waktu tertentu. Pola kedatangan dapat diketahui secara pasti atau berupa suatu variabel acak yang distribusi peluangnya dianggap telah diketahui (Wagner, 1972).

Sebuah model adalah perwakilan dari sebagian dunia nyata atau keseluruhan sistem (the system of interest) yang disederhanakan, yang fokus pada elemen tertentu yang dianggap penting dari sudut pandang tertentu (Ortúzar and Willumsen, 2011). Pilihan yang ada bukan 
lagi menanyakan perlunya membangun model, namun apakah akan membangun model yang eksplisit? Dalam model yang eksplisit, asumsi yang detail menjadi landasan, sehingga bisa dipelajari apa yang dibebankan pada model tersebut. Pada asumsi-asumsi tersebut, rangkaian kejadian berada. Ketika asumsi-asumsi tersebut diubah, berubah pula kejadiannya. Dengan menuliskan model yang eksplisit, peneliti yang lain bisa mengulang hasil pemodel ini (Epstein, 2008). Untuk menghasilkan model yang eksplisit tersebut, diperlukan gambaran yang mewakili sistem terwujud secara matematis (Sokolowski and Banks, 2009).

Pada berbagai capaian manusia dalam berbagai bidang, konstruksi model statistik diperlukan untuk menjelaskan variabel dasar di bidang tersebut. Model paling dasar yang paling banyak digunakan adalah model distribusi peluang. Kaitannya dengan nilai dari variabel dasar yang muncul dari peluangnya (Karian and Dudewicz, 2011). Penggunaan model mampu menjelaskan secara luas suatu hubungan dengan tingkat presisi yang tidak bisa dicapai dengan bahasa alami. Sehingga model bisa menyelesaikan masalah terkait hubungan antara perilaku pada suatu fenomena, dan karakteristik didalamnya yang belum teridentifikasi. Pada akhirnya, dalam kelas model tertentu memungkinkan untuk mempelajari interaksi antar individual pada entitas yang berbeda di tingkat yang lebih rendah yang akan menghasilkan pola pada tingkatan yang lebih tinggi. Interaksi ini terkait khususnya pada ilmu sosial. Dalam ilmu sosial, interaksi antar individu membentuk masyarakat, yang selanjutnya mempengaruhi perilaku indikasi atau kelompok terkait. Karena karakteristik ini, suatu model menarik bagi yang mempelajari masyarakat dari sudut pandang mengelola sendiri (Leeuw, 2004).

Teori Antrian (queueing teory) merupakan studi matematika dari antrian atau kejadian garis tunggu (waiting lines), yakni suatu garis tunggu dari pelanggan yang memerlukan layanan dari sistem pelayanan yang ada. Hal ini sering kita jumpai dalam kegiatan sehari-hari. Ratarata lamanya waktu untuk menunggu sangat bergantung pada rata-rata tingkat kecepatan layanan. Menunggu dapat terjadi karenan kebutuhan akan layanan yang melebihi kapasitas pelayanan yang ada, akan mengakibatkan konsumen yang datang tidak segera terlayani. Pada model antrian, hubungan antara bus dan penumpang adalah berkaitan dengan periode waktu yang diperoleh bus untuk menyelesaikan sebuah antrian (Ahmad, 2012)

Disiplin Antrian di klasifikasikan menjadi dua yaitu prioritas dan first come first serve. Disiplin prioritas dikelompokan menjadi dua, yaitu preemptive dan non preemptive. Disiplin preemptive menggambarkan situasi dimana pelayanan sedang melayani seseorang, kemudian beralih melayani orang yang di prioritaskan meskipun belum selesai melayani orang sebelumnya. Sementara disiplin non preemptive menggambarkan situasi dimanapelayanan akan menyelesaikan pelayanannya baru kemudian beralih melayani orang yang diprioritaskan. Sedangkan disiplin first come first serve menggambarkan bahwa orang yang dating lebih dahulu dating akan dilayai terlebih dahulu (Sitohang, 2006).

Model waktu pelayanan penumpang di halte (dwelling time) sangat sesuai dengan model regresi linier tunggal pada proses penyusun dwelling time. Model dwelling time yang sesuai untuk Bus Trans Jogja adalah penjumlahan dari proses waktu pelayanan penumpang turun, waktu pelayanan penumpang naik, dan waktu pelayanan lain-lain. Model dwelling time yang dibangun dalam penelitian ini sangat spesifik mewakili Bus Trans Jogja yang merupakan bus rintisan BRT. Sebagai rintisan BRT, Bus Trans Jogja memiliki ciri spesifik berupa lantai tinggi, satu pintu untuk keluar masuk, dan dibantu oleh pemandu perjalanan di halte maupun di dalam bus. Kondisi ini tidak ditemui pada penelitian mengenai dwelling time sebelumnya. (Narendra, 2018) 
Distribusi Poisson adalah distribusi binomial dengan kasus kejadian yang terbatas, saat jumlah percobaannya besar dan kemungkinan kejadiannya kecil. "Parameter" dari pendekatan distribusi Poisson adalah jumlah dari "percobaan" dikalikan dengan kemungkinan umumnya, yaitu "harapan" jumlah kejadian (Kaye and Freedman, 2011). Dengan kata lain, distribusi Poisson digunakan saat kejadian mengambil sampel suatu kaveling acak dari ukuran tertentu, yang dari sampel tersebut ada kemungkinan yang rendah untuk mendapatkan yang dicari, sehingga sebagian besar data bernilai nol (McKillup, 2011). Selain itu, sejumlah penumpang yang naik ke atau turun dari bus secara bebas, memiliki pola distribusi Poisson, sehingga jumlah penumpang naik maupun turun dibangkitkan mengikuti pola acak Poisson atau normal (Anderson et al., 1979; Senevirante, 1990).

Sistem Bus Rapid Transit (BRT) adalah angkutan massal yang berbasis pada jalan dimana memanfaatkan jalur-jalur khusus dan ekslusif. Sedangkan Bus Rapid Transit berbasis busway adalah sarana angkutan umum massal dengan moda bus dimana kendaraan akan berjalan pada lintasan khusus berada di sisi jalur cepat. Selain itu sistem yang dipergunakan adalah sistem tertutup dimana penumpang dapat naik dan turun hanya pada halte-halte dan tentunya harus dilengkapi dengan sistem tiket baik berupa tiket untuk sekal jalan ataupun berlangganan dengan mekanisme prabayar (Septiawati, 2017). Menurut Grava (2003), pengguna selalu memilih angkutan yang mempunyai biaya yang termurah, yang antara lain meliputi biaya waktu (termasuk waktu tunggu) dan biaya berjalan (saat berpindah moda)

Bus stop atau halte merupakan tempat untuk menaikkan dan menurunkan penumpang yang terdiri dari satu atau lebih loading area. Kapasitas halte dipengaruhi oleh kapasitas loading area, jumlah loading area dan desain dari loading area, serta ada atau tidaknya sinyal lalu lintas yang mempengaruhi pergerakan bus untuk masuk dan keluar halte (Sianturi, 2008). Halte pada Bus Rapid Transit adalah halte dengan desain khusus untuk membedakan identitas dari pelayanan transportasi lainnya, dengan mencerminkan jenis pelayanan yang prima dan terintegrasi dengan lingkungan sekitar, dan perlu adanya keterlibatan masyarakat atau organisasi professional. Halte Bus Rapid Transit ini juga perlu memperhatikan mengenai keserasiannya dengan lingkungan, fungsinya sebagai ornamen kota, aksesibilitas bagi penyandang cacat, dan lokasi atau penempatan halte yang berdasarkan pada sistem pembagian zona (Sufiani, 2010).

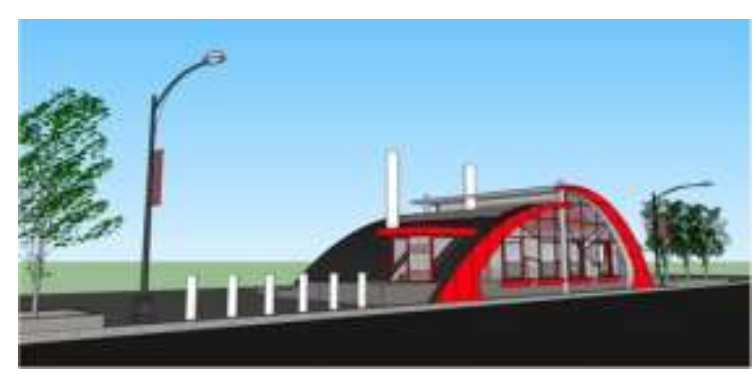

Gambar 1. Desain Halte BRT Trans Semarang

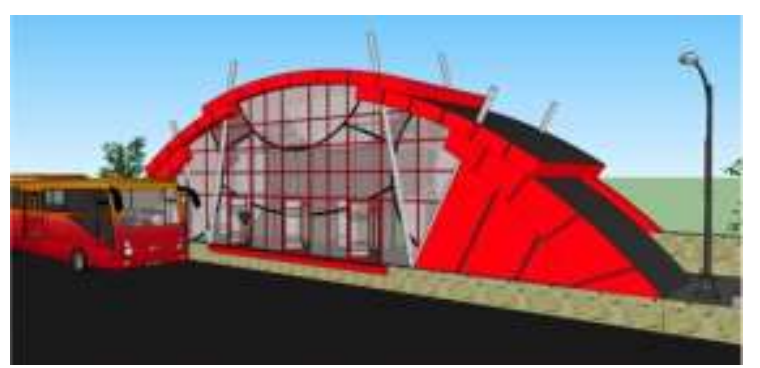

Gambar 2. Desain Halte BRT Trans Semarang

(Sumber : Dokumen BLU UPTD Trans Semarang)

\section{METODE}

Salah satu metode yang dilakukan didalam pelaksanaan penelitian ini dengan survei lapangan ke lokasi, yaitu di halte simpang lima dan halte kampung pelangi dengan merekam dengan kamera 360, Waktu Pelaksanaan survei Halte BRT Simpang Lima pada hari Selasa, Kamis, Sabtu pada tanggal 4, 6 dan 8 Februari 2020 pada pukul 12.00 WIB sampai dengan pukul 17.00 WIB. Dan waktu pelaksanaan survei Halte BRT Kampung Pelangi pada hari Selasa, 
Kamis, Sabtu pada tanggal 11, 13, dan 15 Februari 2020 pada pukul 12.00 WIB sampai dengan pukul 17.00 WIB.setelah itu menghitung jumlah kedatangan penumpang pada halte tersebut untuk mendapatkan data penumpang.

\section{Data Sekunder}

Data sekunder diperoleh dari referensi dan data yang sudah ada untuk memperkuat dan memperdalam isi dalam penelitian tentang pola kedatangan ini diperlukan jurnal-jurnal, bukubuku, dan aturan yang terkait metode penelitian berisi papaparan tentang pendekatan penelitian, metode penelitian, jenis penelitian, tempat penelitian, populasi dan sampel, prosedur penelitian, instrumen dan teknik analisis data.

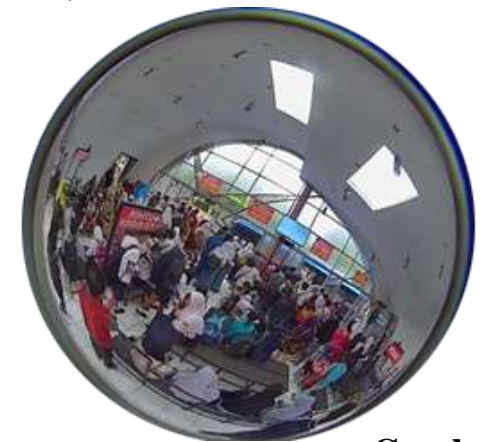

\section{Gambar 3. Screenshot Wide Camera}

\section{HASIL DAN PEMBAHASAN}

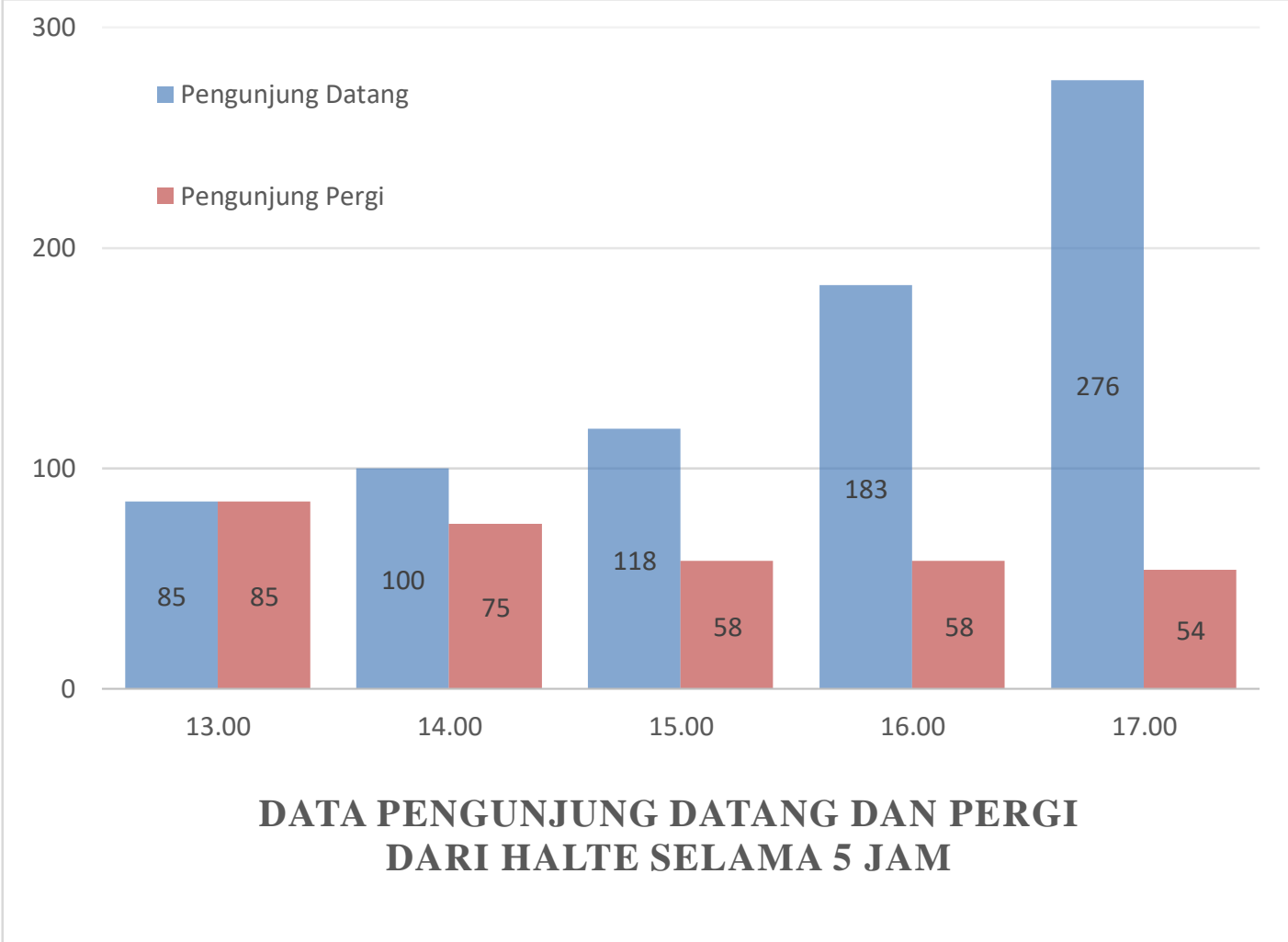

Gambar 4. Hasil Analisis Data Halte BRT Simpang Lima (Selasa, 4 Februari 2020) 


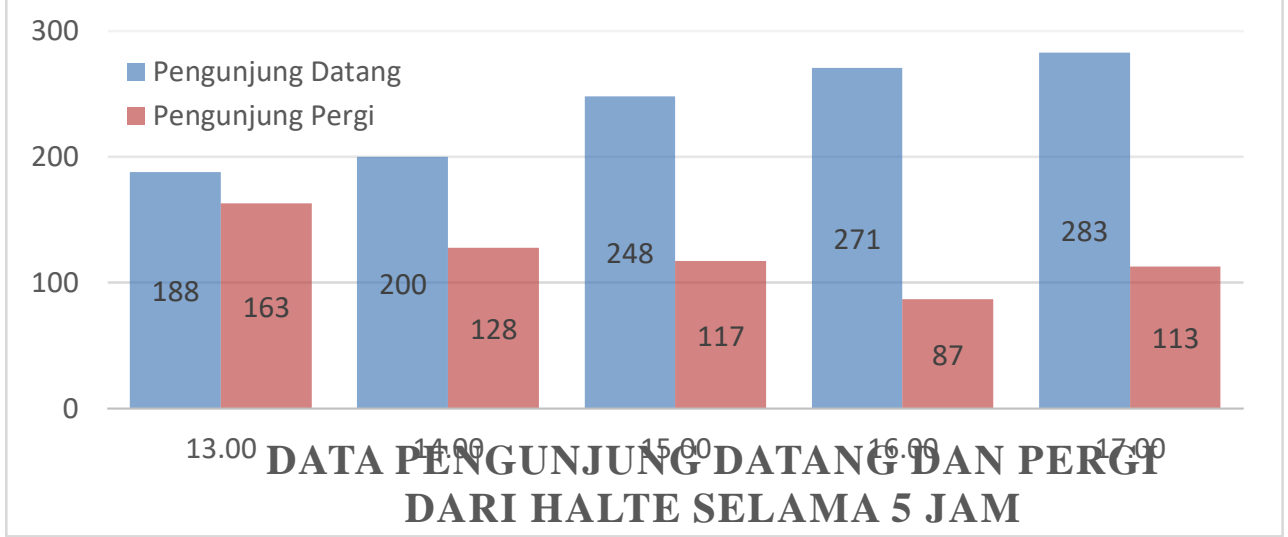

Gambar 5. Hasil analisis data halte BRT Simpang Lima (Kamis, 6 Februari 2020)

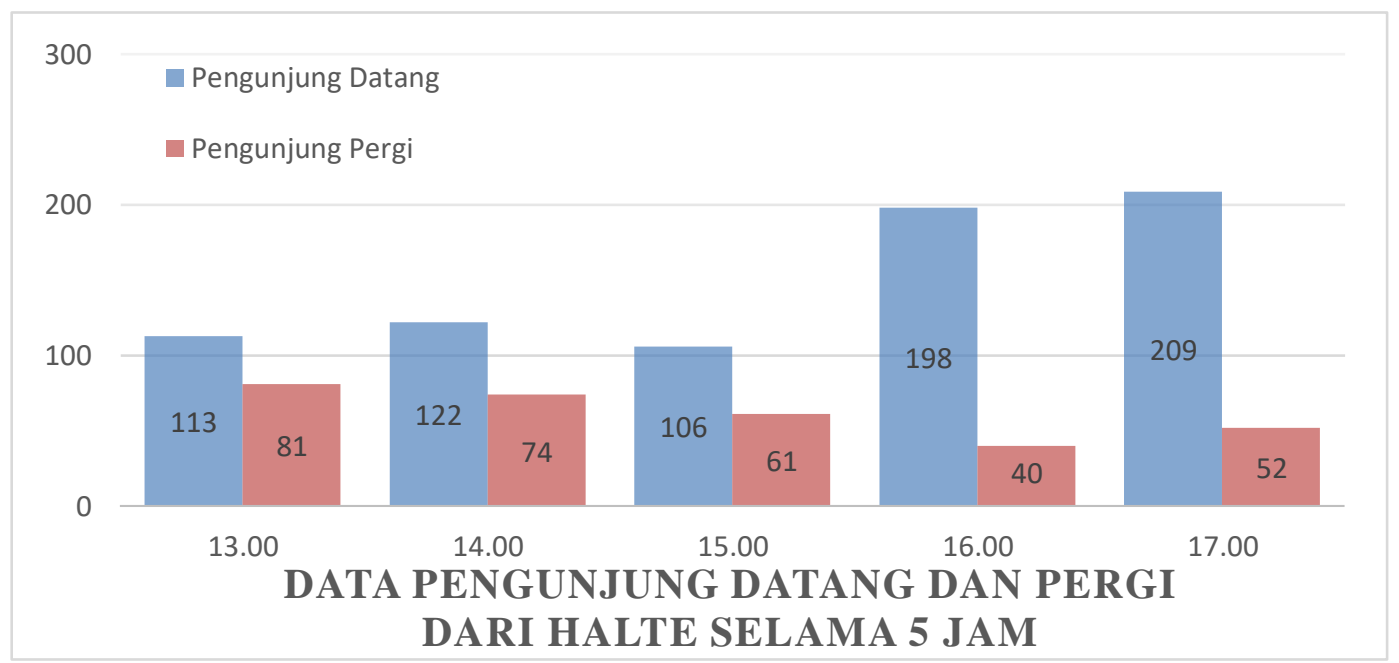

Gambar 6. Hasil Analisis Data Halte BRT Simpang Lima (Selasa, 8 Februari 2020)

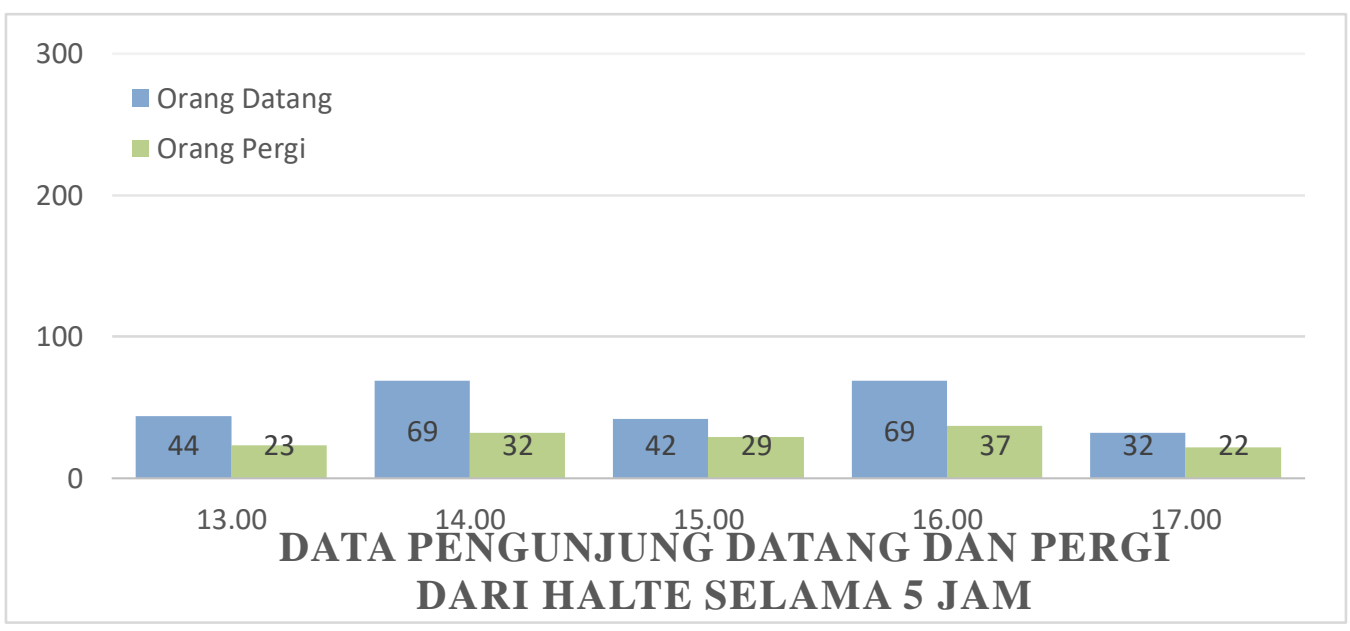

Gambar 7. Hasil analisis data halte BRT Kampung Pelangi 


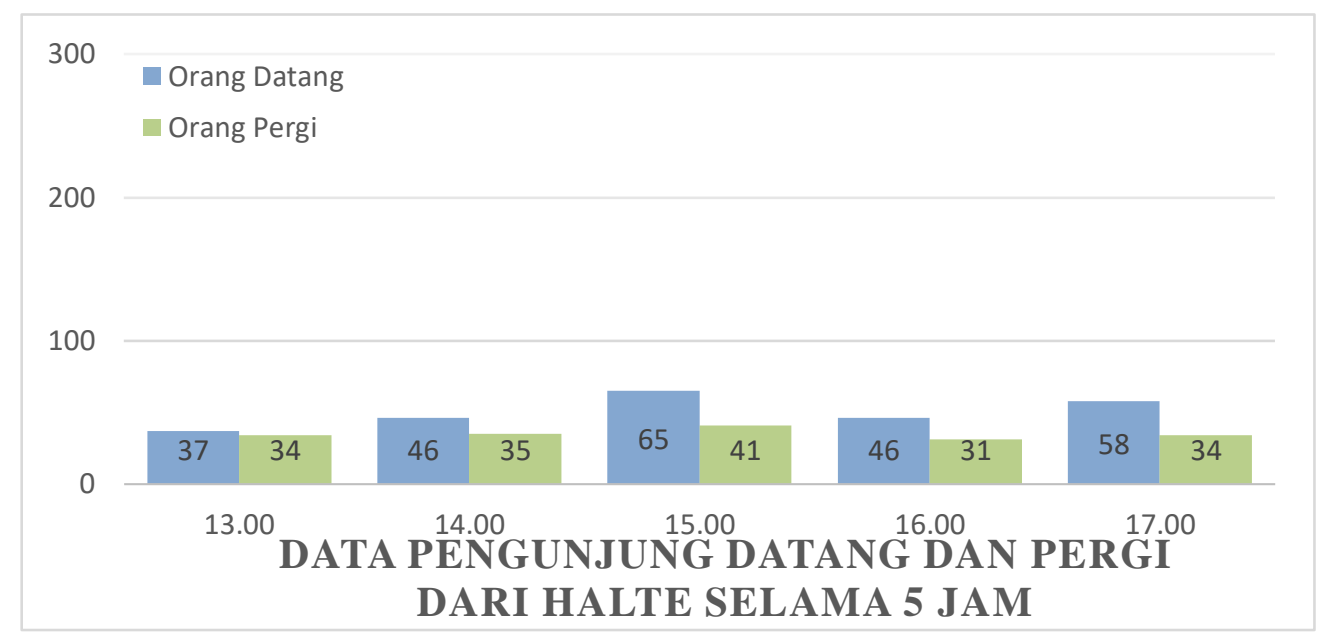

Gambar 8. Hasil analisis data halte BRT Kampung Pelangi (Kamis, 13 Februari 2020)

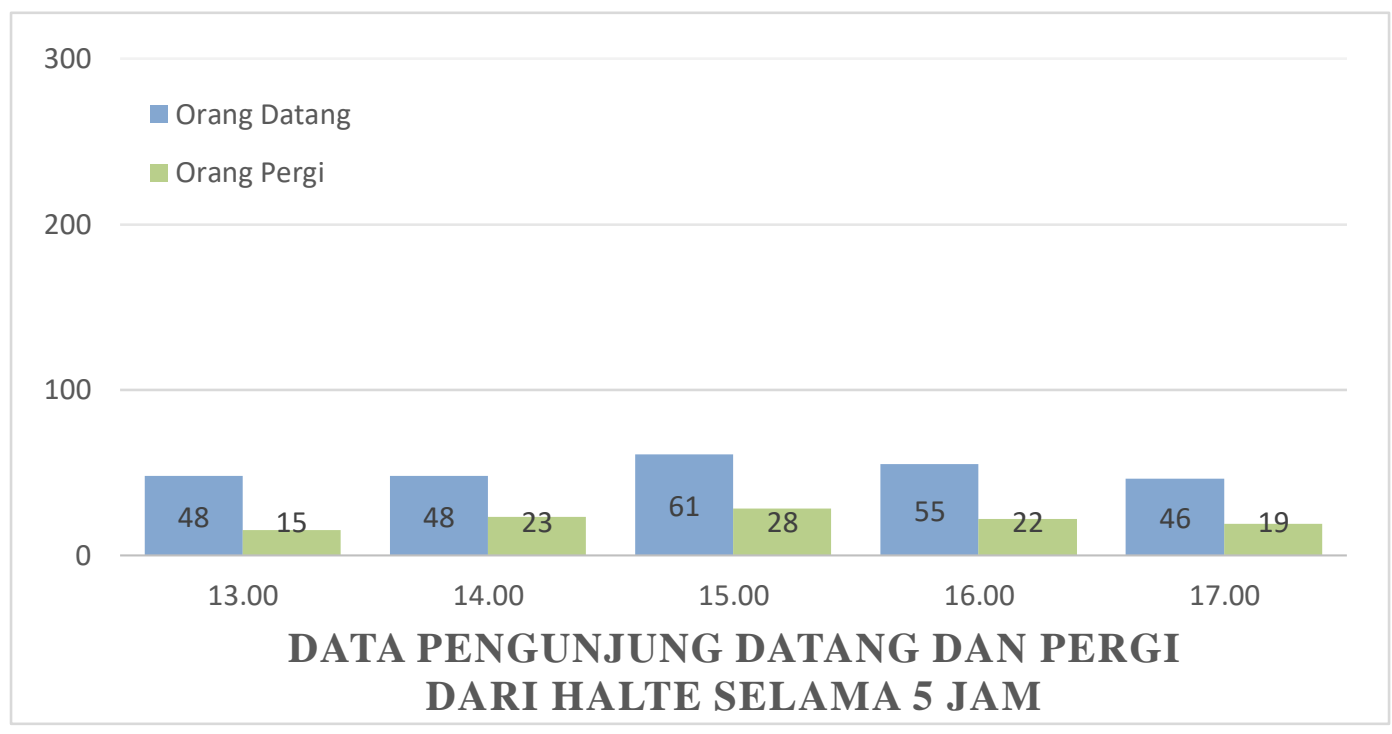

Gambar 9. Hasil Analisis Data Halte BRT Kampung Pelangi (Sabtu, 15 Februari 2020)

Tabel 1.

Hasil Uji Normal dan Poisson Halte BRT Simpang Lima

\begin{tabular}{|c|c|c|c|}
\hline \multirow{2}{*}{ Waktu } & \multicolumn{2}{|c|}{ Normal } & Poisson \\
\cline { 2 - 4 } & Mean & SD & Lambda \\
\hline 5 Menit & 45 & 14.9 & 45 \\
15 Menit & 135 & 40.5 & 135 \\
30 Menit & 270 & 75.7 & 270 \\
60 Menit & 540 & 146.1 & 540 \\
\hline
\end{tabular}


Tabel 2.

Hasil Uji Normal dan Poisson Halte BRT Kampung Pelangi

\begin{tabular}{|c|c|c|c|}
\hline \multirow{2}{*}{ Waktu } & \multicolumn{2}{|c|}{ Normal } & Poisson \\
\cline { 2 - 4 } & Mean & SD & Lambda \\
\hline 5 Menit & 12.7 & 3.81 & 12.7 \\
15 Menit & 38.1 & 6.21 & 38.1 \\
30 Menit & 76.2 & 9.47 & 76.2 \\
60 Menit & 152.4 & 16.81 & 152.4 \\
\hline
\end{tabular}

Tabel 3.

Hasil Uji Shapiro-Wilk Halte BRT Simpang Lima

\begin{tabular}{|c|c|c|}
\hline \multirow{2}{*}{ Waktu } & \multicolumn{2}{|c|}{ Shapiro - Wilk } \\
\cline { 2 - 3 } & P - Value & P - Value < (0.05) \\
\hline 5 Menit & 0.003 & Normal \\
15 Menit & 0.019 & Normal \\
30 Menit & 0.077 & Tidak Normal \\
60 Menit & 0.39 & Tidak Normal \\
\hline
\end{tabular}

Tabel 4.

Hasil Uji Shapiro-Wilk Halte BRT Kampung Pelangi

\begin{tabular}{|c|c|c|}
\hline \multirow{2}{*}{ Waktu } & \multicolumn{2}{|c|}{ Shapiro - Wilk } \\
\cline { 2 - 3 } & P - Value & P - Value < (0.05) \\
\hline 5 Menit & 0.021 & Normal \\
15 Menit & 0.045 & Normal \\
30 Menit & 0.574 & Tidak Normal \\
60 Menit & 0.248 & Normal \\
\hline
\end{tabular}

Tabel 5.

Hasil Uji T-Test dan Wilcoxon Halte BRT Simpang Lima

\begin{tabular}{|c|c|c|c|}
\hline \multirow{2}{*}{ Waktu } & T - Test & \multirow{2}{*}{ Perbandingan } & Wilcoxon ( Whitney - Mann) \\
\cline { 2 - 4 } & P - Value & & P - Value \\
\hline 5 Menit & 0.9 & $>$ & 0.75 \\
15 Menit & 0.68 & $<$ & 0.82 \\
30 Menit & 0.88 & $<$ & 0.92 \\
60 Menit & 0.83 & $<$ & 1 \\
\hline
\end{tabular}


Tabel 6.

Hasil Uji T-Test dan Wilcoxon Halte BRT Kampung Pelangi

\begin{tabular}{|c|c|c|c|}
\hline \multirow{2}{*}{ Waktu } & T -Test & \multirow{2}{*}{ Perbandingan } & Vilcoxon ( Whitney - Mann) \\
\cline { 2 - 4 } & P - Value & & P - Value \\
\hline 5 Menit & 0.43 & $<$ & 0.9 \\
15 Menit & 0.77 & $>$ & 0.28 \\
30 Menit & 0.97 & $>$ & 0.72 \\
60 Menit & 0.96 & $>$ & 0.81 \\
\hline
\end{tabular}

\section{Halte BRT}

Gambar 4. Pengamatan pengunjung dilakukan selama 3 hari yaitu hari Selasa, Kamis, dan Sabtu. Setiap harinya pengamatan dilakukan selama 5 jam pada waktu puncak operasi yaitu sekitar pukul 12.00 - 17.00 WIB. Gambar 1. Hasil Analisis Data Pada Hari Selasa menunjukkan jumlah pengunjung yang datang dan pergi dari Halte Simpang Lima Kota Semarang. Pada pukul 13.00 WIB jumlah pengunjung yang datang ke Halte Simpang Lima Kota Semarang yaitu sebanyak 85 orang dan yang pergi dari Halte Simpang Lima Kota Semarang berjumlah 85 orang. Pukul 14.00 WIB pengunjung yang datang ke Halte Simpang Lima Kota Semarang sebanyak 100 orang dan pengunjung yang pergi dari Halte Simpang Lima Kota Semarang berjumlah 75 orang. Pada pukul 15.00 WIB pengunjung yang datang ke Halte Simpang Lima Kota Semarang berjumlah 118 orang dan pengunjung yang pergi dari Halte Simpang Lima Kota Semarang berjumlah 58 orang. Selanjutnya pada pukul 16.00 WIB jumlah pengunjung yang datang ke Halte Simpang Lima Kota Semarang yaitu 183 orang dan jumlah pengunjung yang pergi dari Halte Simpang Lima Kota Semarang yaitu 58 orang. Untuk yang terakhir pada pukul 17.00 WIB jumlah pengunjung yang datang ke Halte Simpang Lima Kota Semarang yaitu 276 orang dan jumlah pengunjung yang pergi dari Halte Simpang Lima Kota Semarang yaitu 54 orang. Dilihat dari hasil analisis jumlah terbanyak pengunjung yang datang yaitu pada pukul 17.00 WIB bertepatan dengan jam pulang kerja yaitu pukul 16.00 sampai dengan pukul 17.00 WIB.

Gambar 5. Hasil Analisis Data Pada Hari Kamis menunjukkan jumlah pengunjung yang datang dan pergi dari Halte Simpang Lima Kota Semarang. Pada pukul 13.00 WIB jumlah pengunjung yang datang ke Halte Simpang Lima Kota Semarang yaitu sebanyak 113 orang dan yang pergi dari Halte Simpang Lima Kota Semarang berjumlah 81 orang. Pukul 14.00 WIB pengunjung yang datang ke Halte Simpang Lima Kota Semarang sebanyak 122 orang dan pengunjung yang pergi dari Halte Simpang Lima Kota Semarang berjumlah 74 orang. Pada pukul 15.00 WIB pengunjung yang datang ke Halte Simpang Lima Kota Semarang berjumlah 106 orang dan pengunjung yang pergi dari Halte Simpang Lima Kota Semarang berjumlah 61 orang. Selanjutnya pada pukul 16.00 WIB jumlah pengunjung yang datang ke Halte Simpang Lima Kota Semarang yaitu 198 orang dan jumlah pengunjung yang pergi dari Halte Simpang Lima Kota Semarang yaitu 40 orang. Untuk yang terakhir pada pukul 17.00 WIB jumlah pengunjung yang datang ke Halte Simpang Lima Kota Semarang yaitu 209 orang dan jumlah pengunjung yang pergi dari Halte Simpang Lima Kota Semarang yaitu 52 orang. Dilihat dari hasil analisis jumlah terbanyak pengunjung yang datang yaitu pada pukul 17.00 WIB bertepatan dengan jam pulang kerja yaitu pukul 16.00 sampai dengan pukul 17.00 WIB. 
Gambar 6. Hasil Analisis Data Pada Hari Sabtu menunjukkan jumlah pengunjung yang datang dan pergi dari Halte Simpang Lima Kota Semarang. Pada pukul 13.00 WIB jumlah pengunjung yang datang ke Halte Simpang Lima Kota Semarang yaitu sebanyak 188 orang dan yang pergi dari Halte Simpang Lima Kota Semarang berjumlah 163 orang. Pukul 14.00 WIB pengunjung yang datang ke Halte Simpang Lima Kota Semarang sebanyak 200 orang dan pengunjung yang pergi dari Halte Simpang Lima Kota Semarang berjumlah 128 orang. Pada pukul 15.00 WIB pengunjung yang datang ke Halte Simpang Lima Kota Semarang berjumlah 248 orang dan pengunjung yang pergi dari Halte Simpang Lima Kota Semarang berjumlah 117 orang. Selanjutnya pada pukul 16.00 WIB jumlah pengunjung yang datang ke Halte Simpang Lima Kota Semarang yaitu 271 orang dan jumlah pengunjung yang pergi dari Halte Simpang Lima Kota Semarang yaitu 87 orang. Untuk yang terakhir pada pukul 17.00 WIB jumlah pengunjung yang datang ke Halte Simpang Lima Kota Semarang yaitu 283 orang dan jumlah pengunjung yang pergi dari Halte Simpang Lima Kota Semarang yaitu 113 orang.

Gambar 7. Pengamatan pengunjung dilakukan selama 3 hari yaitu hari Selasa, Kamis, dan Sabtu. Setiap harinya pengamatan dilakukan selama 5 jam pada waktu puncak operasi yaitu sekitar pukul 12.00 - 17.00 WIB. Hasil Analisis Data Pada Hari Selasa menunjukkan jumlah pengunjung yang datang dan pergi dari Halte Kampung Pelangi Kota Semarang. Pada pukul 13.00 WIB jumlah pengunjung yang datang ke Halte Kampung Pelangi Kota Semarang yaitu sebanyak 37 orang dan yang pergi dari Kampung Pelangi Kota Semarang berjumlah 34 orang. Pukul 14.00 WIB pengunjung yang datang ke Halte Kampung Pelangi Kota Semarang sebanyak 46 orang dan pengunjung yang pergi dari Halte Kampung Pelangi Kota Semarang berjumlah 35 orang. Pada pukul 15.00 WIB pengunjung yang datang ke Halte Kampung Pelangi Kota Semarang berjumlah 65 orang dan pengunjung yang pergi dari Halte Kampung Pelangi Kota Semarang berjumlah 41 orang. Selanjutnya pada pukul 16.00 WIB jumlah pengunjung yang datang ke Halte Kampung Pelangi Kota Semarang yaitu 46 orang dan jumlah pengunjung yang pergi dari Halte Kampung Pelangi Kota Semarang yaitu 31 orang. Untuk yang terakhir pada pukul 17.00 WIB jumlah pengunjung yang datang ke Halte Kampung Pelangi Kota Semarang yaitu 58 orang dan jumlah pengunjung yang pergi dari Halte Kampung Pelangi Kota Semarang yaitu 34 orang. Dilihat dari hasil analisis jumlah terbanyak pengunjung yang datang yaitu pada pukul 15.00 WIB bertepatan dengan jam pulang sekolah.

Gambar 8.Hasil Analisis Data Pada Hari Kamis menunjukkan jumlah pengunjung yang datang dan pergi dari Halte Kampung Pelangi Kota Semarang. Pada pukul 13.00 WIB jumlah pengunjung yang datang ke Halte Kampung Pelangi Kota Semarang yaitu sebanyak 44 orang dan yang pergi dari Halte Kampung Pelangi Kota Semarang berjumlah 23 orang. Pukul 14.00 WIB pengunjung yang datang ke Halte Kampung Pelangi Kota Semarang sebanyak 69 orang dan pengunjung yang pergi dari Halte Kampung Pelangi Kota Semarang berjumlah 32 orang. Pada pukul 15.00 WIB pengunjung yang datang ke Halte Kampung Pelangi Kota Semarang berjumlah 42 orang dan pengunjung yang pergi dari Halte Kampung Pelangi Kota Semarang berjumlah 29 orang. Selanjutnya pada pukul 16.00 WIB jumlah pengunjung yang datang ke Halte Kampung Pelangi Kota Semarang yaitu 69 orang dan jumlah pengunjung yang pergi dari Halte Kampung Pelangi Kota Semarang yaitu 37 orang. Untuk yang terakhir pada pukul 17.00 WIB jumlah pengunjung yang datang ke Halte Kampung Pelangi Kota Semarang yaitu 32 orang dan jumlah pengunjung yang pergi dari Halte Kampung Pelangi Kota Semarang yaitu 22 orang. Dilihat dari hasil analisis jumlah terbanyak pengunjung yang datang yaitu pada pukul 16.00 WIB bertepatan dengan jam pulang kerja. 
Gambar 9. Hasil Analisis Data Pada Hari Sabtu menunjukkan jumlah pengunjung yang datang dan pergi dari Halte Kampung Pelangi Kota Semarang. Pada pukul 13.00 WIB jumlah pengunjung yang datang ke Halte Kampung Pelangi Kota Semarang yaitu sebanyak 48 orang dan yang pergi dari Halte Kampung Pelangi Kota Semarang berjumlah 15 orang. Pukul 14.00 WIB pengunjung yang datang ke Halte Kampung Pelangi Kota Semarang sebanyak 48 orang dan pengunjung yang pergi dari Halte Kampung Pelangi Kota Semarang berjumlah 23 orang. Pada pukul 15.00 WIB pengunjung yang datang ke Halte Kampung Pelangi Kota Semarang berjumlah 61 orang dan pengunjung yang pergi dari Halte Kampung Pelangi Kota Semarang berjumlah 28 orang. Selanjutnya pada pukul 16.00 WIB jumlah pengunjung yang datang ke Halte Kampung Pelangi Kota Semarang yaitu 55 orang dan jumlah pengunjung yang pergi dari Halte Kampung Pelangi Kota Semarang yaitu 22 orang. Untuk yang terakhir pada pukul 17.00 WIB jumlah pengunjung yang datang ke Halte Kampung Pelangi Kota Semarang yaitu 46 orang dan jumlah pengunjung yang pergi dari Halte Kampung Pelangi Kota Semarang yaitu 19 orang.

\section{Uji Normal dan Poisson Halte BRT}

Tabel 1. Didapat hasil uji normal dan poisson halte brt simpang lima adalah per 5 menit untuk data yang didapat dari uji normal dengan mean 45, nilai sd sebesar 14.9 sedangkan untuk poisson didapat nilai lambda sebesar 45 . Untuk per 15 menit untuk data yang didapat dari uji normal dengan mean 135 , nilai sd sebesar 40.5 sedangkan untuk poisson didapat nilai lambda sebesar 135. Untuk per 30 menit untuk data yang didapat dari uji normal dengan mean 270 , nilai sd sebesar 75.7 sedangkan untuk poisson didapat nilai lambda sebesar 270. Untuk per 60 menit untuk data yang didapat dari uji normal dengan mean 540, nilai sd sebesar 146.1 sedangkan untuk poisson didapat nilai lambda sebesar 540.

Tabel 2. Didapat hasil uji normal dan poisson halte brt kampung Pelangi adalah per 5 menit untuk data yang didapat dari uji normal dengan mean 12.7, nilai sd sebesar 3.81 sedangkan untuk poisson didapat nilai lambda sebesar 12.7. Untuk per 15 menit untuk data yang didapat dari uji normal dengan mean 38.1, nilai sd sebesar 6.21 sedangkan untuk poisson didapat nilai lambda sebesar 38.1. Untuk per 30 menit untuk data yang didapat dari uji normal dengan mean 76.2, nilai sd sebesar 9.47 sedangkan untuk poisson didapat nilai lambda sebesar 76.2. Untuk per 60 menit untuk data yang didapat dari uji normal dengan mean 152.4, nilai sd sebesar 16.81 sedangkan untuk poisson didapat nilai lambda sebesar 152.4.

\section{Uji Shapiro-Wilk}

Hasil uji Shapiro-Wilk, P-Value tidak semua normal maka menggunakan 2 distribusi yaitu TTest dan Wilcoxon (Whitney-Mann) untuk mencari perbandingan P-Value Mana yang lebih kecil / mendekati Normal.

\section{Uji T-Test dan Wilcoxon (Whitney-Mann)}

P-Value yang dicari adalah yang lebih kecil / mendekati normal. Dari tabel 5 terlihat untuk waktu per 5 menit yang diambil adalah P-Value Wilcoxon (Uji Hipotesis data penumpang aktual dengan data pnp simulasi poisson) karena lebih kecil, sedangkan untuk waktu per 15 menit, 30 menit dan 60 menit yang diambil adalah P-Value T-test (Uji hipotesis data penumpang aktual dengan data pnp simulasi normal). P-Value yang dicari adalah yang lebih kecil / mendekati normal. Dari tabel 6 terlihat untuk waktu per 5 menit yang diambil adalah PValue T-test karena lebih kecil, sedangkan untuk waktu per 15 menit, 30 menit dan 60 menit yang diambil adalah P-Value Wilcoxon. 


\section{SIMPULAN}

Hasil analisis menunjukkan bahwa jumlah pengunjung datang dan pergi tertinggi pada halte brt simpang lima yaitu pada hari sabtu dengan jumlah pengunjung datang yaitu 1190 orang dan jumlah pengunjung pergi yaitu 608 orang yang dibagi menjadi 5 periode jam. Pengunjung dengan kedatangan tertinggi terjadi pada pukul 16.00-17.00 WIB, sebanyak 283 orang. Sedangkan pengunjung yang meninggalkan halte teringgi terjadi pada pukul 12.00-13.00 WIB, sebanyak 163 orang. Sedangkan jumlah pengunjung datang dan pergi pada halte brt kampung pelangi tidak begitu ada perbedaan yang signifikan yaitu sekitar 250 orang untuk yang datang dan yang pergi 150 orang yang dibagi 5 periode jam. Jam puncak halte brt kampung pelangi pada kisaran pukul 15.00-16.00 WIB.

Studi ini menemukan bahwa mean pada uji normal sama dengan lambda pada uji poisson. Dan dilanjutkan ke uji Shapiro-Wilk, Karena P-Value tidak semua normal maka menggunakan 2 distribusi yaitu T-Test dan Wilcoxon (Whitney-Mann) untuk mencari perbandingan P-Value Mana yang lebih kecil / mendekati Normal. Hasil analisis dari uji t-test (normal) dan wilcoxon (poisson) untuk diambil p-value yang lebih kecil/mendekalti normal, dari tabel 5 menunjukkan bahwa pada halte brt simpang lima p-value per 5 menit lebih kecil dengan uji wilcoxon dan untuk per 15 menit, 30 menit dan 60 menit lebih kecil dengan uji ttest. Sedangkan pada tabel 6 halte brt kampung pelangi p-value per 5 menit lebih kecil dengan uji t-test dan untuk per 15 menit, 30 menit dan 60 menit lebih kecil dengan uji wilcoxon. Jadi dari uji di t-test dan wilcoxon yang mendekati data aktual adalah kedatangan penumpang per 5 menit dengan distribusi yang sesuai untuk halte simpang lima adalah wilcoxon (poisson) dengan p-value 0.75 dan distribusi yang sesuai untuk halte kampung pelangi adalah t-test (normal) dengan p-value 0.43 .

\section{DAFTAR PUSTAKA}

Alfa Narendra. 2018. Pemodelan Perpindahan Moda Dalam Trayek Trans Jogja. Laporan Disertasi. Program Studi Doktor Teknk Sipil, Universitas Gadjah Mada, Yogyakarta.

Septiawati, F. 2017. Analisis Pelayanan Transjabodetabek Rute Poris PlawadBundaran Senayan Sebagai Moda Transportasi Angkutan Massal Penduduk Pinggiran Ke Pusat Kota. Jurnal Pembangunan Wilayah Dan Kota. Vol 13 (2), 203-216.

Sufiani, A. 2010. Analisis Kinerja Pelayanan Terminal Busway. Skripsi. Program Studi Teknik Sipil. Universitas Indonesia. Jakarta.

Ahmad, Z., E., dan Devianto, D. 2012. Identidikasi Model Antrian Pada Antrian Bus Kampus Universitas Andalas Padang. Jurnal Matematika UNAND. Vol 1 (2), 44-51.

Safril, M., B., Lumiu, M., M., dan Chriestie, E., J., C. 2018. Model Sistem Antrian dengan Menggunakan Pola Kedatangan dan Pola Pelayanan Pemohon SIM di Satuan Penyelenggaraan Adminstrasi SIM Resort Kepolisian Manado. Jurnal Matematika dan Aplikasi Decartesian. Vol 7 (1), 15-21.

Alfiani, A., R., Sugito, dan Sudarno. 2013. Analisis Model Waktu Antar Kedatangan dan Waktu Pelayanan Pada Bagian Pembayaran Kasir Instalasi Rawat Inap RSUP Dr Kariadi Semarang. Prosiding Seminar Nasional Statistika. Universitas Diponegoro. Semarang. 